ISSN 1392-3196 / e-ISSN 2335-8947

Zemdirbyste-Agriculture, vol. 107, No. 3 (2020), p. 279-286

DOI 10.13080/z-a.2020.107.036

\title{
Impact of sowing date on bread wheat kernel quantitative and qualitative traits under Middle East climate conditions
}

\author{
Shahryar SASANI ${ }^{1}$, Reza AMIRI ${ }^{2}$, Hamid Reza SHARIFI ${ }^{3}$, Ali LOTFI $^{1}$ \\ ${ }^{1}$ Crop and Horticultural Sciences Research Department, \\ Kermanshah Agricultural and Natural Resources Research and Education Center, \\ Agricultural Research Education and Extension Organization (AREEO) \\ Kermanshah, Iran \\ E-mail: shahryarsasani@gmail.com \\ ${ }^{2}$ Crop and Horticultural Sciences Research Department, \\ Lorestan Agricultural and Natural Resources Research and Education Center, \\ Agricultural Research Education and Extension Organization (AREEO) \\ Khorramabad, Iran \\ ${ }^{3}$ Crop and Horticultural Sciences Research Department, \\ Khorasan Razavi Agricultural and Natural Resources Research and Education Center, \\ Agricultural Research Education and Extension Organization (AREEO) \\ Mashhad, Iran
}

\begin{abstract}
The current study explored the effects of six spring wheat (Triticum aestivum L.) cultivars, four sowing dates (early, timely, late and very late) and their interactions on quantitative and qualitative traits during two cropping years. A combined analysis of variance (ANOVA) indicated that the effect of sowing date was significant on kernel yield and filling period. The quality traits were not significantly affected by the sowing date. Interaction of sowing date $\times$ cultivar $\times$ year was significant for some quantity and quality traits including yield, filling period, sedimentation value and gluten index. Average kernel yield reduction of all the cultivars, measured under late and very late planting, was $34 \%$ and $50 \%$ of optimum sown (November) in 2013-2014, and 25\% and 38\% in 2014-2015, respectively. For most of the studied traits, the effect of year was confirmed on higher level compared to the effect of cultivar or sowing date. The range for cultivar effect was high for thousand kernel weight, medium for gluten index and low for the other traits. The sowing date had the highest contribution to kernel yield followed by filling period and wet gluten, respectively. Negative relationship was observed between quality traits and kernel yield, but quality traits significantly and positively correlated with each other. In summary, the quality and quantity potential of wheat can be exploited by planting it at optimum time.
\end{abstract}

Key words: gluten, kernel yield, protein, timely sown, thousand kernel weight, Zeleny and SDS sedimentation values.

\section{Introduction}

Wheat plays an important role in feeding the growing world population due to its high content of protein and essential minerals, vitamins and other phytochemicals (Dao et al., 2017; Nadew, 2018). Like in many parts of the world, bread and other wheat-kernel products are the main daily sources of food in Iran (Amiri et al., 2015), where they are eaten in various forms at breakfast, lunch and dinner due to being a ready-toaccess and ready-to-eat food products.

Nowadays, bread-making quality has become increasingly important. For this reason, development of high-yield as well as high-quality bread wheat responding to improved agricultural practices has become a primary objective for plant breeders. Evaluation of wheat baking quality involves numerous tests of traits such as protein concentration, gluten index, hardness index, water absorption, sedimentation value, falling number, etc. (Peña et al., 2002; Kurt-Polat, Yagdi, 2017; Doneva et al., 2018). Baking quality of wheat is mostly determined by protein quantity and quality grading. The gluten-forming protein is responsible for bread making quality (Laidig et al., 2017). Many researchers have declared that protein is the most important component of wheat kernel (Koppel, Ingver, 2010). Although the range of kernel protein content in wheat cultivars has been found to be wide, it's mostly reported values range from $8 \%$ to $17 \%$, which depend on the genotype and environmental factors (Peña et al., 2002).

It is well known that wheat flour strength is based on the gluten quantity and quality, which play a key role in determining the unique baking quality of wheat (Ferrari et al., 2014). Almost $80 \%$ to $90 \%$ of the proteins are glutens (Sivam et al., 2010). Therefore, both protein concentration and gluten quality, the two most important factors influencing bread baking quality, are of overall importance in determining industrial use (Ferrari et al., 2014). Moreover, kernel texture, as an important factor in determining the milling behaviour of

Please use the following format when citing the article:

Sasani S., Amiri R., Sharifi H. R., Lotfi A. 2020. Impact of sowing date on bread wheat kernel quantitative and qualitative traits under Middle East climate conditions. Zemdirbyste-Agriculture, 107 (3): 279-286. DOI 10.13080/z-a.2020.107.036 
wheat, is closely related to other quality traits and used as a grading factor to determine the wheat kernel type as hard or soft (Sun et al., 2018). Generally, soft wheat is used for baking cookies and cakes, whereas hard wheat is used mostly in baking bread. Therefore, the milling and baking industries prefer hard wheat to achieve good mill and acceptable baker quality (Simons et al., 2012).

Water absorption, defined as amount of water needed to hydrate flour components to produce dough with optimum consistency, is an essential ingredient in dough making through allowing proteins to form a gluten matrix (Mastromatteo et al., 2013). Generally, higher protein content causes increasing water absorption in the flour and leads to larger loaf volume and softer bread. The sedimentation values (according to Zeleny and SDS tests) defined as a quick test for determination of the superior bread-making quality and gluten strength of wheat flour, have gained acceptance as small-scale and useful tests in bread wheat breeding programs (Gazza et al., 2016).

It is widely known that wheat kernel quality is a complex heritable trait, which is often related to cultivar's genetic constitution but strongly influenced by the environment (climatic, production conditions, location, etc.) and also the genotype $\times$ environment interaction (Peña et al., 2002; Nikola et al., 2010). Among different factors affecting kernel quantity and quality crop management aspects such as cultivar selection, planting density and sowing date are known as effective factors with very important role (Zecevic et al., 2014). Different sowing time provides variations in growth period, days with air temperature and kernel filling duration that is appropriate for crop growth (Kong et al., 2013). Therefore, the proper selection of a sowing date can have a considerable positive impact on both the quantity and quality of crop yield (Singh et al., 2010) by regulating the thermal conditions and precipitation, particularly during kernel filling period as well as avoiding or minimizing the exposure to adverse environmental conditions (Tapley et al., 2013).

Late planting can affect the crop performance through poor germination, which causes reduction in growth of individual plants and tiller production under low temperatures. In contrast, early sowing produces higher yields due to longer duration of kernel development. Moreover, it should be noted that early planting of spring wheat cultivars will cause frost damage in plants due to accelerated entry into the reproductive phase. Therefore, sowing wheat at optimum time according to environmental conditions may be a proper way to increase growth, yield and quality traits of kernels. Good management of the sowing dates, cultivars and other agricultural conditions can lead to an increase in wheat kernel yield by $10 \%$ to $80 \%$ (Coventry et al., 2011). Adverse environmental conditions during anthesis and kernel filling are important factors determining wheat baking quality (Jiang et al., 2009).

Comprehensive knowledge about sowing date effects on quality traits should help breeders to select specific traits validated across locations and years, because acceptable kernel yield along with kernel quality are the key goals in breeding programs. As a result, the aim of the current study was to explore the effects of cultivars, sowing dates and their interactions on the quantitative and qualitative traits in commercial bread wheat cultivars in moderate climate zone of Iran during two consecutive cropping cycles.

\section{Materials and methods}

Plant material used in the current study consisted of six spring bread wheat (Triticum aestivum L.) cultivars 'Chamran-2', 'Parsi', 'Pishtaz', 'Bahar', 'Sirwan' and 'Sivand'. Field experiment was conducted at Eslamabade-Gharb Agricultural Research Station $\left(34^{\circ} 08^{\prime}\right.$ N, 46 $26^{\prime}$ E, $1346 \mathrm{~m}$ a.s.l.), Kermanshah Agricultural and Natural Resources Research and Education Centre, Agricultural
Research, Education and Extension Organization (AREEO), Kermanshah, Iran across two consecutive cropping seasons (2013-2014 and 2014-2015). In both years, the experiment followed a randomized complete block design with split plot arrangement, placing sowing dates in the main plots and cultivars in sub-plots with three replicates. The treatments were four sowing dates (early, timely, late and very late) and six bread wheat cultivars. Based on the soil sample analysis, soil texture was silty clay; $\mathrm{pH}$ was 7.4 with 0.6 as electrical conductivity (EC), phosphorus $\left(\mathrm{PO}_{4}^{3-}\right)$ content $16.8 \mathrm{ppm}$, organic carbon $\left(\mathrm{C}^{2}\right) 1.2 \%$, potassium $\left(\mathrm{K}^{+}\right)$content 770 ppm, magnesium $\left(\mathrm{Mn}^{2+}\right) 7.6 \mathrm{ppm}$, its iron $\left(\mathrm{Fe}^{2+}\right)$ content $6.3 \mathrm{ppm}$, zinc $\left(\mathrm{Zn}^{2+}\right) 2.2 \mathrm{ppm}$ and the copper $\left(\mathrm{Cu}^{2+}\right)$ $1.9 \mathrm{ppm}$. Sowing in the 2013-2014 growing season was carried out on 10 October, 7 November, 3 December and 31 December, in the 2014-2015 growing season - on 12 October, 1 November, 22 November and 14 December. Each plot was $2.4 \mathrm{~m}$ wide and $8 \mathrm{~m}$ long, containing twelve rows and a density of 400 seeds per square meter. The plots were machine-drilled by a seeder Wintersteiger and when necessary treated with fertilizers, herbicides, pesticides and fungicides according to farmers' practice for intensive wheat production. Total rainfall from sowing to harvesting was 505 and $312 \mathrm{~mm}$ in the 2013 2014 and 2014-2015 growing seasons, respectively. Average temperatures were mostly similar during the first $\left(12.8^{\circ} \mathrm{C}\right)$ and second $\left(13.6^{\circ} \mathrm{C}\right)$ experimental years.

At full physiological maturity, all the rows of each plot were machine-harvested by a small-plot combine harvester Wintersteiger. Wheat kernel yield per plot was converted from $\mathrm{g} \mathrm{plot}^{-1}$ to $\mathrm{kg} \mathrm{ha}^{-1}$ based on kernel moisture content to determine final yield. A thousand kernel weight (TKW) was measured by using a Contador seed counter (Pfeuffer GmbH, Germany). Different kernel quality traits were measured at Cereals Technology and Chemistry Laboratory of Seed and Plant Improvement Institute in Karaj, AREEO, Alborz province, Iran. Kernel protein, sedimentation value (according to Zeleny), bread volume, hardness index, moisture percent and flour water absorption were determined by near infrared reflectance (NIR) spectrometer (Osborne et al., 2007). All these parameters were determined based on AACC (2000) standard methods using an instrument 8600 (Perten Instruments, Sweden). To determine gluten-related traits, the whole kernels were milled by a laboratory mill 3100 (Perten Instruments). Wet gluten was prepared from whole meal by the Glutomatic 2200 gluten washer (Perten Instruments). A gluten index centrifuge 2015 (Perten Instruments) was used to force the wet gluten through a specially designed sieve cassette (AACC, 2000). The sodium dodecyl sulphate (SDS) sedimentation value of the flour samples was estimated according to the ICC standard 116/1 (Determination of the sedimentation value (according to Zeleny) as an approximate measure of baking quality).

All data sets were checked for normal frequency distribution and equality of variance before data analysis. Simple and combined analyses of variance (ANOVA) and means comparison were done using the statistical packages $S A S$, version 9.1 (SAS Institute Inc., USA) and MSTAT-C, version 2.10 (Michigan State University, USA). Mean separations were estimated using Duncan's multiple range test at $5 \%$ probability levels, whenever treatment differences were significant. The software SPSS, version 16.0 (SPSS Inc., USA) was used for calculating Pearson correlation among the years. Tables and graphs were constructed using Microsoft Office Excel.

\section{Results and discussion}

Combined analysis of variance (ANOVA) and mean comparison. Results of combined ANOVA indicated that effect of year (cropping season) was significant $(P<0.01)$ on all studied traits except spring wheat kernel yield, thousand kernel weight (TKW), bread volume, wet gluten and gluten index (Table 1). 
Table 1. Combined analysis of variance (ANOVA) for the spring wheat kernel traits as affected by sowing date and cultivar across two cropping seasons

\begin{tabular}{|c|c|c|c|c|c|c|c|}
\hline \multirow[b]{2}{*}{ SOV } & \multirow[b]{2}{*}{ DF } & \multicolumn{6}{|c|}{ Mean squares } \\
\hline & & yield & $\begin{array}{c}\text { thousand kernel } \\
\text { weight }\end{array}$ & $\begin{array}{l}\text { filling } \\
\text { period }\end{array}$ & $\begin{array}{c}\text { moisture } \\
\text { percent }\end{array}$ & $\begin{array}{l}\text { hardness } \\
\text { index }\end{array}$ & $\begin{array}{l}\text { protein } \\
\text { content }\end{array}$ \\
\hline Year $(\mathrm{Y})$ & 1 & $43739484 \mathrm{~ns}$ & $114.5257 \mathrm{~ns}$ & $1508.0278 * *$ & $43.012^{* *}$ & $336.1111 * *$ & $1.6684^{* *}$ \\
\hline Replication / Y & 4 & 8673100 & 20.3759 & 30.1111 & 0.187 & 3.8611 & 0.0213 \\
\hline Sowing date (A) & 3 & $120496047 *$ & $13.5949 \mathrm{~ns}$ & $586.5740 *$ & $0.028 \mathrm{~ns}$ & $0.4907 \mathrm{~ns}$ & $0.0203 \mathrm{~ns}$ \\
\hline$A \times Y$ & 3 & $13939842 * *$ & $29.8023 * *$ & $25.9352 *$ & $0.014 \mathrm{~ns}$ & $3.0185^{*}$ & $0.0358^{*}$ \\
\hline Error $\left(\mathrm{E}_{\mathrm{a}}\right)$ & 12 & 1019994 & 2.2796 & 6.9074 & 0.037 & 0.5463 & 0.0093 \\
\hline Cultivar (B) & 5 & $3791700 \mathrm{~ns}$ & $118.0845 * *$ & $52.4778 *$ & $0.009 \mathrm{~ns}$ & $9.1611 \mathrm{~ns}$ & $0.2367 \mathrm{~ns}$ \\
\hline $\mathrm{B} \times \mathrm{Y}$ & 5 & $1756992 * *$ & $10.5059 *$ & $7.8278 \mathrm{~ns}$ & $0.014 \mathrm{~ns}$ & $4.9111 * *$ & $0.2827 * *$ \\
\hline $\mathrm{A} \times \mathrm{B}$ & 15 & $2270162 \mathrm{~ns}$ & $3.7709 \mathrm{~ns}$ & $2.5407 \mathrm{~ns}$ & $0.019 \mathrm{~ns}$ & $0.5130 \mathrm{~ns}$ & $0.0121 \mathrm{~ns}$ \\
\hline $\mathrm{A} \times \mathrm{B} \times \mathrm{Y}$ & 15 & $1126818 * *$ & $5.9518 \mathrm{~ns}$ & $8.0463 *$ & $0.025 \mathrm{~ns}$ & $0.5741 \mathrm{~ns}$ & $0.0255 \mathrm{~ns}$ \\
\hline Error $\left(E_{b}\right)$ & 80 & 439989 & 4.2151 & 3.5667 & 0.024 & 0.9000 & 0.0180 \\
\hline \multirow[t]{2}{*}{$\mathrm{CV} \%$} & - & 8.88 & 5.07 & 5.44 & 1.42 & 1.80 & 1.14 \\
\hline & & \multicolumn{6}{|c|}{ Mean squares } \\
\hline $\mathrm{SOV}$ & DF & $\begin{array}{l}\text { sedimentation } \\
\text { value (Zeleny) }\end{array}$ & $\begin{array}{l}\text { bread } \\
\text { volume }\end{array}$ & $\begin{array}{c}\text { water } \\
\text { absorption }\end{array}$ & $\begin{array}{c}\text { wet } \\
\text { gluten }\end{array}$ & $\begin{array}{l}\text { gluten } \\
\text { index }\end{array}$ & $\begin{array}{l}\text { sedimentation } \\
\text { value (SDS) }\end{array}$ \\
\hline Year $(\mathrm{Y})$ & 1 & $39.0625 * *$ & $1.56 \mathrm{~ns}$ & $3.8678 * *$ & $171.1736 \mathrm{~ns}$ & $2240.44 \mathrm{~ns}$ & $61.3611 * *$ \\
\hline Replication / Y & 4 & 0.3889 & 1530.83 & 0.0844 & 67.4306 & 347.66 & 2.1528 \\
\hline Sowing date (A) & 3 & $0.7292 \mathrm{~ns}$ & $581.30 \mathrm{~ns}$ & $0.0936 \mathrm{~ns}$ & $58.8958 \mathrm{~ns}$ & $489.37 \mathrm{~ns}$ & $1.4259 \mathrm{~ns}$ \\
\hline $\mathrm{A} \times \mathrm{Y}$ & 3 & $0.4699 \mathrm{~ns}$ & $1071.06 \mathrm{~ns}$ & $0.2052 \mathrm{~ns}$ & $25.3773 \mathrm{~ns}$ & $1020.78 \mathrm{~ns}$ & $3.0463 \mathrm{~ns}$ \\
\hline Error $\left(\mathrm{E}_{\mathrm{a}}\right)$ & 12 & 0.2315 & 650.81 & 0.0751 & 19.0602 & 565.76 & 2.5694 \\
\hline Cultivar (B) & 5 & $1.2569 \mathrm{~ns}$ & $755.35 \mathrm{~ns}$ & $0.2413 \mathrm{~ns}$ & $19.4125 \mathrm{~ns}$ & $2449.13 *$ & $8.2778 \mathrm{~ns}$ \\
\hline $\mathrm{B} \times \mathrm{Y}$ & 5 & $1.2458 * *$ & $719.78 \mathrm{~ns}$ & $0.2538^{*}$ & $4.7569 \mathrm{~ns}$ & $339.01 \mathrm{~ns}$ & $18.3611 * *$ \\
\hline $\mathrm{A} \times \mathrm{B}$ & 15 & $0.2569 \mathrm{~ns}$ & $695.90 \mathrm{~ns}$ & $0.0919 \mathrm{~ns}$ & $3.5125 \mathrm{~ns}$ & $306.64 \mathrm{~ns}$ & $1.4148 \mathrm{~ns}$ \\
\hline $\mathrm{A} \times \mathrm{B} \times \mathrm{Y}$ & 15 & $0.6088^{*}$ & $627.12 \mathrm{~ns}$ & $0.0774 \mathrm{~ns}$ & $1.8495 \mathrm{~ns}$ & $333.08^{*}$ & $1.2463 \mathrm{~ns}$ \\
\hline Error $\left(E_{h}\right)$ & 80 & 0.3042 & 536.45 & 0.1064 & 4.1778 & 186.19 & 1.3069 \\
\hline $\mathrm{CV} \%$ & - & 1.69 & 4.87 & 0.51 & 8.69 & 29.45 & 2.00 \\
\hline
\end{tabular}

Note. SOV - sources of variation, CV - coefficient of variation, DF - degrees of freedom; SDS - sodium dodecyl sulphate; * $* *$ significant at the $P$ levels of $<0.05$ and $<0.01$, respectively; ns - non significant.

Results revealed significant $(P<0.05)$ differences among investigated sowing dates for kernel yield and filling period. The kernel yield, TKW, filling period as well as hardness index and protein content were significantly influenced by the interaction of sowing date and year. TKW, filling period and gluten index were the only traits with significant differences among cultivars. All studied traits except kernel filling period, moisture percent, hardness index, protein content, water absorption and sedimentation values (according to Zeleny and SDS tests) were significantly affected by cultivar $\times$ year interaction. ANOVA showed that none of the examined traits were significantly influenced by sowing time $x$ cultivar interaction. The influence of sowing date $x$ cultivar $\times$ year interaction was significant on kernel yield, filling period, sedimentation value (according to Zeleny) and gluten index (Table 1). Hence, the cultivars showed no similar reaction to sowing date, year or their combinations. This result was in close agreement with the findings of Pan et al. (2005), who reported the influence of environment, genotype and sowing time interactions on wheat end-use quality indicators.

Mean comparison of the studied traits as influenced by year $\times$ sowing date (Table 2 ) showed that notwithstanding some statistical similarity, the highest value of TKW (42.00 g), hardness index (54.67) and protein content $(11.97 \%)$ in average for all cultivars was recorded for plants sown on 31 December in the 20132014 cropping season. Plants sown on 14 December in 2014-2015 had the lowest TKW (37.86 g). The minimum value of hardness index $(50.94)$ and protein content (11.66\%) was recorded for 22 November sowing date in the 2014-2015 cropping season, which was not statistically different from the other sowing dates in this year (Table 2).

Table 2. Mean comparison of the studied spring wheat kernel traits as influenced by year $\times$ sowing date

\begin{tabular}{|c|c|c|c|c|c|c|c|c|}
\hline \multirow{2}{*}{ Trait } & \multicolumn{4}{|c|}{$2013-2014$} & \multicolumn{4}{|c|}{$2014-2015$} \\
\hline & 1010 & 0711 & 0312 & 3112 & 1210 & 0111 & 2211 & 1412 \\
\hline Thousand kernel weight $\mathrm{g}$ & $40.31 \mathrm{~b}$ & $41.65 \mathrm{a}$ & $41.38 \mathrm{ab}$ & $42.00 \mathrm{a}$ & $40.21 \mathrm{bc}$ & $41.02 \mathrm{ab}$ & $39.12 \mathrm{c}$ & $37.86 \mathrm{~d}$ \\
\hline Hardness index & $53.78 \mathrm{~b}$ & $54.22 \mathrm{ab}$ & $54.17 \mathrm{ab}$ & $54.67 \mathrm{a}$ & $51.44 \mathrm{c}$ & $51.28 \mathrm{c}$ & $50.94 \mathrm{c}$ & $50.94 \mathrm{c}$ \\
\hline Protein content $\%$ & $11.87 \mathrm{~b}$ & $11.89 \mathrm{~b}$ & $11.93 \mathrm{ab}$ & $11.97 \mathrm{a}$ & $11.71 \mathrm{c}$ & $11.73 \mathrm{c}$ & $11.66 \mathrm{c}$ & $11.71 \mathrm{c}$ \\
\hline
\end{tabular}

Note. Significant difference according to Duncan's multiple range test at $P$ level of $<0.05$ for different letters within each column.

In average for all sowing dates, 'Sirwan' and 'Parsi' in 2013-2014 had the highest TKW, while the lowest value was obtained by 'Bahar' in 2014-2015 and 'Sivand' in both cropping seasons (Table 3). The highest value of qualitative traits such as hardness index (55.83), protein content $(12.19 \%)$, water absorption $(64.72 \%)$ and sedimentation value (according to SDS) $(59.83 \mathrm{ml})$ was recorded for 'Pishtaz' in the 2013-2014 cropping season notwithstanding a few statistical similarities. The lowest hardness index (50.17), protein content $(11.56 \%)$ and water absorption $(63.93 \%)$ were recorded for 'Bahar' in the 2014-2015 cropping season. 'Chamran-2' in 2013-2014 had the lowest sedimentation value (according to SDS) $(55.67 \mathrm{ml})$ among all treatment combinations (Table 3$)$

Mean comparison of the kernel yield as influenced by year $\times$ sowing date $\times$ cultivar is shown in Figure 1 . Cultivars 'Parsi' and 'Sirwan' sown on 7 November in the 2013-2014 cropping season were the first two superior high yielding treatments, whereas 'Bahar' and 'Sivand' $\times$ 31 December $\times 2013-2014$ were the worst treatments. It has been documented how sowing date can affect wheat yield and yield components of wheat (Kristó et al., 2007) as well as quality traits (Silva et al., 2014). Average kernel yield reduction of all the cultivars, measured under late and very late planting, was $34 \%$ and $50 \%$ of optimum sown (November) in 2013-2014, and $25 \%$ and $38 \%$ in 2014-2015, respectively. Late planted crop usually suffers a yield decline due to the exposure to drought stress and high temperature at critical growth stages.

In addition, a delay in sowing date reduces vegetative growth period by the effect of thermal requirement completion growing degree days (GDD) and entry into reproductive phase without sufficient assimilate accumulation for remobilization stage. Moreover, under late sowing, germination and seedling growth became more important for stand establishment. Instead, timely- 
Table 3. Mean comparison of the studied spring wheat kernel traits as influenced by year $\times$ cultivar

\begin{tabular}{|c|c|c|c|c|c|c|}
\hline Cropping season & Cultivar & $\begin{array}{c}\text { Thousand kernel } \\
\text { weight } \\
\text { g }\end{array}$ & $\begin{array}{c}\text { Hardness } \\
\text { index }\end{array}$ & $\begin{array}{l}\text { Protein } \\
\text { content } \\
\%\end{array}$ & $\begin{array}{c}\text { Water } \\
\text { absorption } \\
\% \%\end{array}$ & $\begin{array}{l}\text { SDS sedimentation } \\
\text { value } \\
\text { ml }\end{array}$ \\
\hline \multirow{6}{*}{ 2013-2014 } & Chamran-2 & $\frac{\mathrm{s}}{41.41 \mathrm{~b}}$ & $53.75 b$ & $11.78 \mathrm{bc}$ & $64.25 \mathrm{bcd}$ & $55.67 \mathrm{~d}$ \\
\hline & Parsi & $43.71 \mathrm{a}$ & $53.75 \mathrm{~b}$ & $11.93 \mathrm{ab}$ & $64.27 \mathrm{bcd}$ & $57.33 \mathrm{bc}$ \\
\hline & Pishtaz & $41.94 \mathrm{~b}$ & $55.83 \mathrm{a}$ & $12.19 \mathrm{a}$ & $64.72 \mathrm{a}$ & $59.83 \mathrm{a}$ \\
\hline & Bahar & $39.41 \mathrm{~cd}$ & $54.17 \mathrm{~b}$ & $11.92 \mathrm{ab}$ & $64.41 \mathrm{~b}$ & $58.00 \mathrm{~b}$ \\
\hline & Sirwan & $44.37 \mathrm{a}$ & $53.67 \mathrm{~b}$ & $11.89 \mathrm{~b}$ & $64.32 \mathrm{bc}$ & $58.00 \mathrm{~b}$ \\
\hline & Sivand & $37.18 \mathrm{e}$ & $54.08 \mathrm{~b}$ & $11.78 \mathrm{bc}$ & $64.18 \mathrm{~b}-\mathrm{e}$ & $57.25 \mathrm{bc}$ \\
\hline \multirow{6}{*}{ 2014-2015 } & Chamran-2 & $40.46 \mathrm{bc}$ & $52.08 \mathrm{c}$ & $11.94 \mathrm{ab}$ & 64.04 cde & $57.42 \mathrm{bc}$ \\
\hline & Parsi & $41.11 \mathrm{bc}$ & $51.08 \mathrm{de}$ & $11.57 \mathrm{c}$ & 64.07 cde & $55.67 \mathrm{~d}$ \\
\hline & Pishtaz & $39.45 \mathrm{~cd}$ & $51.83 \mathrm{~cd}$ & $11.78 \mathrm{bc}$ & 64.03 cde & $56.42 \mathrm{~cd}$ \\
\hline & Bahar & $36.96 \mathrm{e}$ & $50.17 \mathrm{f}$ & $11.56 \mathrm{c}$ & $63.93 \mathrm{e}$ & $56.00 \mathrm{~d}$ \\
\hline & Sirwan & $41.59 \mathrm{~b}$ & $51.00 \mathrm{e}$ & $11.67 \mathrm{bc}$ & $64.12 \mathrm{~b}-\mathrm{e}$ & $56.08 \mathrm{~d}$ \\
\hline & Sivand & $37.74 \mathrm{de}$ & 50.75 ef & $11.69 \mathrm{bc}$ & $63.98 \mathrm{de}$ & $56.67 \mathrm{~cd}$ \\
\hline
\end{tabular}

Note. SDS - sodium dodecyl sulphate; significant difference according to Duncan's multiple range test at $P$ level of $<0.05$ for different letters within each column.

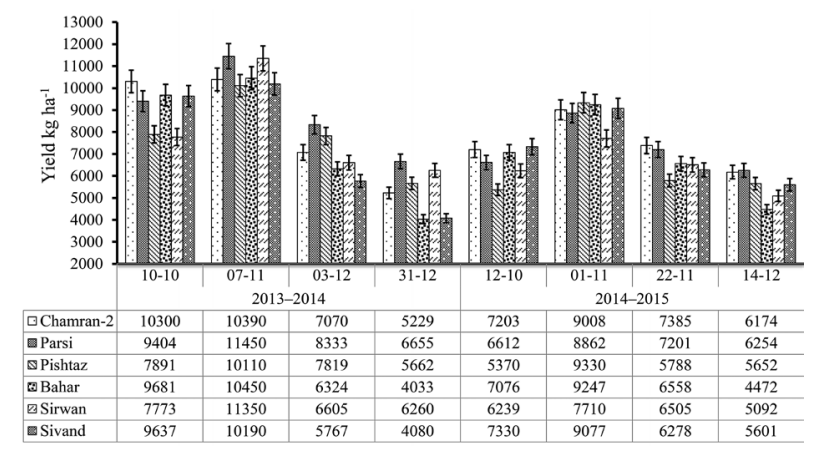

Note. The bars show an error amount of $5 \%$.

Figure 1. Mean comparison of the spring wheat kernel yield as influenced by year $\times$ sowing date $\times$ cultivar

sown crop obtained yield potential as a result of relatively favourable weather conditions during the vegetative growth stage. A delay in planting date reduces GDD for tiller development and higher plant populations are required to compensate for less tiller development.

Average kernel yield decline due to early sowing time (10-12 October) was $14 \%$ and $25 \%$ compared with optimum sowing time in the 2013-2014 and 2014-2015 cropping seasons, respectively. This decrease in kernel yield could be attributed to low temperatures during anthesis stage, which affected the viability of pollen grains and consequently reduced the pollination. These results showed that yield potential of wheat can be exploited by planting it at optimum time, which has been emphasized by other studies (Bassu et al., 2009; Tapley et al., 2013). There was an increase in kernel yield for all the sowing dates in 2013-2014 compared with 2014-2015, which may be a result of a higher amount of rainfall with better distribution, specifically during the critical stages of plant development. Significant reduction in yield has been observed due to the rise in temperature, and it was concluded that a $1.8^{\circ} \mathrm{C}$ rise in temperature caused $3-10 \%$ reduction in wheat yields (You et al., 2009).

The cultivars 'Pishtaz', 'Parsi', 'Sivand', 'Bahar' and 'Sirwan' sown on 10 October in the 2013-2014 cropping season had the longest kernel filling period (more than 43 days) (data not shown). 'Sirwan' and 'Chamran-2' planted on 22 November and 14 December in the 2014 2015 cropping season were the first two treatments with short filling period (28 days). When the cultivars were sown at the optimum dates, filling period was longer (3339 days) than under stress of late planting (29-35 days) and very late planting (28-34 days). The kernel filling period of the cultivars was five days shorter when planted late and very late in both years, indicating forced maturity due to high temperatures. The sedimentation value (according to Zeleny) was the highest in 'Pishtaz' sown on 7 November, 3 December and 31 December and also in 'Parsi' sown on 3 December, all in the 2013-2014 cropping season (data not shown). This trait was the lowest in 'Bahar' planted on 12 October and 14 December and also in 'Sirwan' planted on 22 November, all in the 2014-2015 cropping season.

The gluten index was the highest in 'Sirwan' (81.33\%) planted on 14 December in the 2013-2014 cropping season, while the lowest gluten index was found in 'Sivand' $(19.33 \%)$ planted on 12 October in the 2014 2015 cropping season (data not shown). In conclusion, the effects of some interactions (treatment combinations) were significant on the traits. This means that cultivars showed no similar reaction to sowing date, year or their interactions. Therefore, a summary for simple ANOVA and mean comparison in the 2013-2014 and 2014-2015 cropping seasons was subsequently presented separately.

Expression of the percentage of combined ANOVA components. The contribution of each sources of variation (SOV) for the studied traits (after elimination of errors including replication / year, $\mathrm{E}_{\mathrm{a}}$ and $\mathrm{E}_{\mathrm{b}}$ ) is shown in Figure 2 as percentage of total squares. The range for genotypic variation (cultivar effect) was high for TKW $(57.13 \%)$, medium for gluten index $(40.40 \%)$ and low for the other traits. A remarkably low genotypic effect (lower than $10 \%$ ) was found for kernel yield, filling period, moisture percent and sedimentation value (according to Zeleny). The sowing date had the highest contribution to kernel yield $(68.76 \%)$, filling period $(46.24 \%)$ and wet gluten $(28.26 \%)$, respectively. However, qualitative traits were not as greatly influenced by the sowing date as kernel yield and filling period. This indicated the greater influence of environmental factors on the phenotypic expression of these traits.

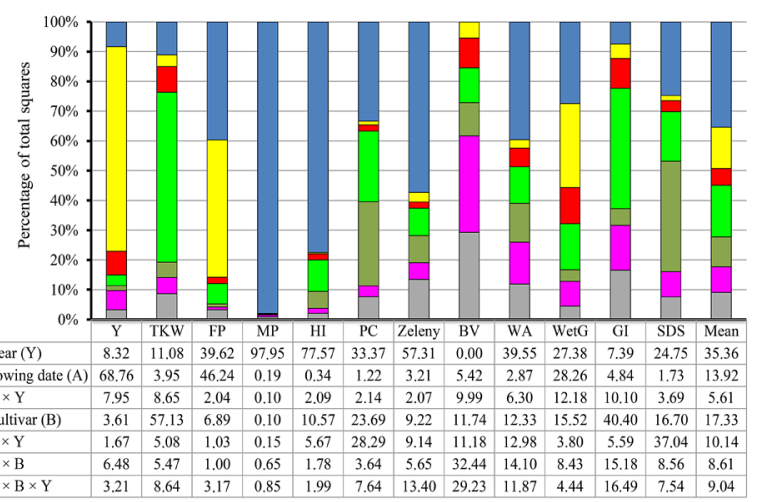

Note. The column mean represents the average across traits; $\mathrm{Y}-$ yield, TKW - thousand kernel weight, FP - filling period, MP - moisture percent, HI - hardness index, PC - protein content, Zeleny - sedimentation value according to Zeleny, BV - bread volume, WA - water absorption, WetG - wet gluten, GI - gluten index, SDS - sedimentation value according to sodium dodecyl sulphate.

Figure 2. Display sources of variation (SOV) of the studied spring wheat kernel traits (after elimination of errors including replication / year, $\mathrm{E}_{\mathrm{a}}$ and $\mathrm{E}_{\mathrm{b}}$ ) as percentage of total squares 
It suggested that the influence of environmental factors on the expression of these traits was high and traits were not amenable enough to early generation's selection and, therefore, their improvement will be practically difficult. It is reported that contributions of the location, year and sowing dates are proportionally greater than the main effect of the genotype and interactions (Zhang et al., 2006). Year affects caused $97.95 \%$ of the total variation for moisture percent followed by hardness index $(77.57 \%)$, sedimentation value (according to Zeleny) (57.31\%), water absorption $(39.55 \%)$ and protein content $(33.37 \%)$. This means that for these traits, year to year variation is remarkably high as compared to variation caused by other components, suggesting that testing of cultivars across the years may be more important than testing of cultivars across different sowing dates, especially when financial resources are limited. The factor most contributing to variation in protein content was year $(33.37 \%)$ followed by cultivar $\times$ year interaction $(28.29 \%)$ and cultivar $(23.69 \%)$. It is thus well known that protein content depends largely on the genotype and the environment (Guarda et al., 2004). The only remarkable effect of sowing date $\times$ cultivar $(32.44 \%)$ and year $\times$ sowing date $\times$ cultivar $(29.23 \%)$ was seen for bread volume. The rightmost column "mean" in Figure 2 represents the average percentage of each SOV over the traits. According to this column, the influence of year $(35.36 \%)$ was more than twice as large as that of cultivar (17.33\%) and triple as large as that of sowing date $(13.92 \%)$.
Descriptive statistics and variability. The results of simple ANOVA (Table 4) revealed significant effect of sowing dates on wheat kernel yield, TKW, filling period and hardness index in 2013-2014, and yield, TKW, filling period and protein content in 2014 2015. Cultivars had the highest significant effect on all studied traits in both years except on moisture percent and bread volume in the 2013-2014 cropping season and moisture percent, bread volume and water absorption in the 2014-2015 cropping season.

The interaction effect between sowing dates and genotypes was found significant for kernel yield and filling period in 2013-2014 and 2014-2015, respectively. Results of mean comparison (data not shown) indicated that in average for all cultivars, the highest TKW was recorded for plants sown on 31 December $(42.00 \mathrm{~g})$ in 2013-2014 and on 1 November (41.02 g) in the 2014-2015 cropping seasons. The high TKW at optimum sowing date might be due to the suitable environmental conditions for vegetative growth, which resulted in active photosynthesis and high assimilate translocation to kernels. Early sowing date (10 October) in 2013-2014 resulted in increasing filling period compared with optimum, late and very late sowing dates. In the 2014-2015 cropping season, wheat sown on 1 November (timely sown) and 14 December (very late sown) had the highest (8872 $\left.\mathrm{kg} \mathrm{ha}^{-1}\right)$ and the lowest (5541 $\mathrm{kg} \mathrm{ha}^{-1}$ ) kernel yield, respectively. The highest value for protein content $(11.73 \mathrm{~g})$ was obtained when wheat was timely sown on 1 November.

Table 4. Simple analysis of variance (ANOVA) for the studied spring wheat kernel traits in the two cropping seasons

\begin{tabular}{|c|c|c|c|c|c|c|c|c|}
\hline \multirow{2}{*}{$\begin{array}{l}\text { Cropping } \\
\text { season }\end{array}$} & \multirow[b]{2}{*}{ SOV } & \multirow[b]{2}{*}{$\mathrm{DF}$} & \multicolumn{6}{|c|}{ Mean squares } \\
\hline & & & yield & $\begin{array}{c}\text { thousand kernel } \\
\text { weight }\end{array}$ & $\begin{array}{l}\text { filling } \\
\text { period }\end{array}$ & $\begin{array}{c}\text { moisture } \\
\text { percent }\end{array}$ & $\begin{array}{l}\text { hardness } \\
\text { index }\end{array}$ & $\begin{array}{l}\text { protein } \\
\text { content }\end{array}$ \\
\hline \multirow{7}{*}{ 2013-2014 } & Replication & 2 & $7565433^{*}$ & $3.578 \mathrm{~ns}$ & $45.931^{* *}$ & $0.367^{*}$ & $2.667 *$ & $0.015 \mathrm{~ns}$ \\
\hline & Sowing date (A) & 3 & $99129069 * *$ & $9.562 * *$ & $423.681 * *$ & $0.038 \mathrm{~ns}$ & $2.384 *$ & $0.038 \mathrm{~ns}$ \\
\hline & Error $\left(\mathrm{E}_{\mathrm{a}}\right)$ & 6 & 987219 & 0.797 & 0.986 & 0.047 & 0.370 & 0.015 \\
\hline & Cultivar (B) & 5 & $3548789 * *$ & $86.765 * *$ & $19.214^{* *}$ & $0.016 \mathrm{~ns}$ & $8.092 * *$ & $0.269 * *$ \\
\hline & $\mathrm{A} \times \mathrm{B}$ & 15 & $2355714 * *$ & $3.662 \mathrm{~ns}$ & $4.058 \mathrm{~ns}$ & $0.021 \mathrm{~ns}$ & $0.462 \mathrm{~ns}$ & $0.017 \mathrm{~ns}$ \\
\hline & Error $\left(E_{b}\right)$ & 40 & 301676 & 4.152 & 4.422 & 0.020 & 0.644 & 0.017 \\
\hline & $\mathrm{CV} \%$ & - & 6.85 & 4.93 & 5.54 & 1.23 & 1.48 & 1.10 \\
\hline \multirow{7}{*}{ 2014-2015 } & Replication & 2 & $9780766^{*}$ & $37.174^{*}$ & $14.292 \mathrm{~ns}$ & $0.006 \mathrm{~ns}$ & $5.056^{*}$ & $0.028 *$ \\
\hline & Sowing date (A) & 3 & $35306818 * *$ & $33.836^{*}$ & $188.829 * *$ & $0.004 \mathrm{~ns}$ & $1.125 \mathrm{~ns}$ & $0.018^{*}$ \\
\hline & Error $\left(\mathrm{E}_{\mathrm{a}}\right)$ & 6 & 1052769 & 3.762 & 12.829 & 0.027 & 0.722 & 0.004 \\
\hline & Cultivar (B) & 5 & $1999902 *$ & $41.826^{* *}$ & $41.092 * *$ & $0.006 \mathrm{~ns}$ & $5.981 * *$ & $0.250 * *$ \\
\hline & $\mathrm{A} \times \mathrm{B}$ & 15 & $1041267 \mathrm{~ns}$ & $6.061 \mathrm{~ns}$ & $6.529 *$ & $0.023 \mathrm{~ns}$ & $0.625 \mathrm{~ns}$ & $0.021 \mathrm{~ns}$ \\
\hline & Error $\left(E_{b}\right)$ & 40 & 578301 & 4.279 & 2.711 & 0.028 & 1.156 & 0.019 \\
\hline & $\mathrm{CV} \%$ & - & 10.99 & 5.23 & 5.23 & 1.63 & 2.10 & 1.17 \\
\hline \multirow{2}{*}{$\begin{array}{l}\text { Cropping } \\
\text { season }\end{array}$} & \multirow[b]{2}{*}{ SOV } & \multirow[b]{2}{*}{ DF } & \multicolumn{6}{|c|}{ Mean squares } \\
\hline & & & $\begin{array}{c}\text { sedimentation } \\
\text { value (Zeleny) }\end{array}$ & $\begin{array}{c}\text { bread } \\
\text { volume }\end{array}$ & $\begin{array}{c}\text { water } \\
\text { absorption }\end{array}$ & $\begin{array}{c}\text { wet } \\
\text { gluten }\end{array}$ & $\begin{array}{l}\text { gluten } \\
\text { index }\end{array}$ & $\begin{array}{l}\text { sedimentation } \\
\text { value (SDS) }\end{array}$ \\
\hline \multirow{7}{*}{ 2013-2014 } & Replication & 2 & $0.514 \mathrm{~ns}$ & $2900.38^{* *}$ & $0.073 \mathrm{~ns}$ & $133.597 \mathrm{~ns}$ & $269.39 \mathrm{~ns}$ & $1.764 \mathrm{~ns}$ \\
\hline & Sowing date (A) & 3 & $1.148 \mathrm{~ns}$ & $1022.61 \mathrm{~ns}$ & $0.273 \mathrm{~ns}$ & $66.778 \mathrm{~ns}$ & $302.26 \mathrm{~ns}$ & $3.866 \mathrm{~ns}$ \\
\hline & Error $\left(\mathrm{E}_{\mathrm{a}}\right)$ & 6 & 0.440 & 249.76 & 0.122 & 31.486 & 433.09 & 1.227 \\
\hline & Cultivar (B) & 5 & $1.956 * *$ & $716.13 \mathrm{~ns}$ & $0.446^{*}$ & $14.056^{*}$ & $1415.32 * *$ & $22.081 * *$ \\
\hline & $\mathrm{A} \times \mathrm{B}$ & 15 & $0.526 \mathrm{~ns}$ & $651.13 \mathrm{~ns}$ & $0.126 \mathrm{~ns}$ & $2.30 \mathrm{~ns}$ & $254.60 \mathrm{~ns}$ & $1.932 \mathrm{~ns}$ \\
\hline & Error $\left(E_{b}\right)$ & 40 & 0.408 & 561.22 & 0.154 & 4.197 & 153.93 & 1.394 \\
\hline & $\mathrm{CV} \%$ & - & 1.93 & 4.98 & 0.61 & 8.32 & 29.27 & 2.05 \\
\hline \multirow{7}{*}{$2014-2015$} & Replication & 2 & $0.264 * *$ & $161.29 \mathrm{~ns}$ & $0.095 \mathrm{~ns}$ & $1.264 \mathrm{~ns}$ & $425.93 \mathrm{~ns}$ & $2.542 \mathrm{~ns}$ \\
\hline & Sowing date (A) & 3 & $0.051 \mathrm{~ns}$ & $629.76 \mathrm{~ns}$ & $0.025 \mathrm{~ns}$ & $17.495 \mathrm{~ns}$ & $1207.89 \mathrm{~ns}$ & $0.606 \mathrm{~ns}$ \\
\hline & Error $\left(\mathrm{E}_{\mathrm{a}}\right)$ & 6 & 0.023 & 1051.87 & 0.028 & 6.634 & 698.43 & 3.912 \\
\hline & Cultivar (B) & 5 & $0.547 *$ & $758.99 \mathrm{~ns}$ & $0.049 \mathrm{~ns}$ & $10.114^{*}$ & $1372.82 * *$ & $4.558 * *$ \\
\hline & $\mathrm{A} \times \mathrm{B}$ & 15 & $0.340 \mathrm{~ns}$ & $671.89 \mathrm{~ns}$ & $0.044 \mathrm{~ns}$ & $3.062 \mathrm{~ns}$ & $385.11 \mathrm{~ns}$ & $0.729 \mathrm{~ns}$ \\
\hline & Error $\left(\mathrm{E}_{\mathrm{b}}\right)$ & 40 & 0.200 & 511.69 & 0.058 & 4.158 & 218.44 & 1.219 \\
\hline & CV \% & - & 1.39 & 4.75 & 0.38 & 9.09 & 29.40 & 1.96 \\
\hline
\end{tabular}

Note. SOV - sources of variation, CV - coefficient of variation, DF - degrees of freedom; SDS - sodium dodecyl sulphate; *, ** significant at the $P$ levels of $<0.05$ and $<0.01$, respectively; ns - non significant.

In average for all sowing dates, 'Pishtaz' had the highest value of the traits except TKW in the 20132014 cropping season (Table 5). The highest TKW was recorded for 'Sirwan' (44.37 g) and 'Parsi' (43.71 g). In the 2014-2015 cropping season, maximum kernel yield was recorded for 'Chamran-2' (7443 kg ha-1) followed by 'Parsi' (7233 kg ha') and 'Sivand' ( $\left.7071 \mathrm{~kg} \mathrm{ha}^{-1}\right)$. 'Sirwan' had the highest TKW in the 2014-2015 cropping season, which was not statistically different from that of 'Parsi' and 'Chamran-2'. Moreover, 'Sirwan' was located on top rank for wet gluten and gluten index. Data on hardness index, protein content and sedimentation values (according to Zeleny and SDS tests) revealed that 'Chamran-2' was the best cultivar.

As reported by Williams et al. (1988), bread wheat quality is classified by its kernel protein content as very low $(\leq 9.0 \%)$, low $(9.1-11.5 \%)$, medium $(11.6-$ $13.5 \%)$, high $(13.6-15.5 \%)$, very high $(15.6-17.5 \%)$ and extra high $(\geq 17.6 \%)$. In the current study, in average for all sowing dates, the protein content of the studied cultivars varied from $11.78 \%$ to $12.19 \%$ (in 2013-2014) and $11.56 \%$ to $11.94 \%$ (in 2014-2015), and they can be 
Table 5. Mean comparison of the studied spring wheat kernel traits as influenced by cultivar in the two cropping seasons

\begin{tabular}{|c|c|c|c|c|c|c|c|c|c|c|}
\hline $\begin{array}{l}\text { Crop- } \\
\text { ping } \\
\text { season }\end{array}$ & Cultivar & $\begin{array}{l}\text { Thousand } \\
\text { kernel } \\
\text { weight g }\end{array}$ & $\begin{array}{l}\text { Filling } \\
\text { period, } \\
\text { day }\end{array}$ & $\begin{array}{l}\text { Hardness } \\
\text { index }\end{array}$ & $\begin{array}{l}\text { Protein } \\
\text { content } \\
\% \%\end{array}$ & $\begin{array}{c}\text { Sedimentation } \\
\text { value (Zeleny) } \\
\mathrm{ml}\end{array}$ & $\begin{array}{c}\text { Water } \\
\text { absorption } \\
\% \frac{0}{0}\end{array}$ & $\begin{array}{l}\text { Wet } \\
\text { gluten } \\
\mathrm{g}\end{array}$ & $\begin{array}{l}\text { Gluten } \\
\text { index } \\
\%\end{array}$ & $\begin{array}{c}\text { Sedimentation } \\
\text { value (SDS) } \\
\text { ml }\end{array}$ \\
\hline \multirow{6}{*}{$\begin{array}{c}2013- \\
2014\end{array}$} & Chamran-2 & $41.41 \mathrm{~b}$ & $36.33 \mathrm{~b}$ & $53.75 \mathrm{~b}$ & $11.78 \mathrm{c}$ & $32.75 \mathrm{~b}$ & $64.25 \mathrm{~b}$ & $23.50 \mathrm{c}$ & $48.08 \mathrm{a}$ & $55.67 \mathrm{c}$ \\
\hline & Parsi & $43.71 \mathrm{a}$ & $39.33 \mathrm{a}$ & $53.75 \mathrm{~b}$ & $11.93 \mathrm{~b}$ & $33.08 \mathrm{~b}$ & $64.27 \mathrm{~b}$ & $23.92 \mathrm{bc}$ & $32.00 \mathrm{~b}$ & $57.33 \mathrm{~b}$ \\
\hline & Pishtaz & $41.94 \mathrm{~b}$ & $39.33 \mathrm{a}$ & $55.83 \mathrm{a}$ & $12.19 \mathrm{a}$ & $33.83 \mathrm{a}$ & $64.72 \mathrm{a}$ & $24.58 \mathrm{abc}$ & $57.25 \mathrm{a}$ & $59.83 \mathrm{a}$ \\
\hline & Bahar & $39.41 \mathrm{c}$ & $38.17 \mathrm{ab}$ & $54.17 \mathrm{~b}$ & $11.92 \mathrm{~b}$ & $33.25 \mathrm{~b}$ & $64.41 \mathrm{ab}$ & $26.17 \mathrm{a}$ & $32.50 \mathrm{~b}$ & $58.00 \mathrm{~b}$ \\
\hline & Sirwan & $44.37 \mathrm{a}$ & $36.75 \mathrm{~b}$ & $53.67 \mathrm{~b}$ & $11.89 \mathrm{~b}$ & $33.00 \mathrm{~b}$ & $64.32 \mathrm{~b}$ & $25.67 \mathrm{ab}$ & $50.33 \mathrm{a}$ & $58.00 \mathrm{~b}$ \\
\hline & Sivand & $37.18 \mathrm{~d}$ & $37.67 \mathrm{ab}$ & $54.08 \mathrm{~b}$ & $11.78 \mathrm{c}$ & $32.75 \mathrm{~b}$ & $64.18 \mathrm{~b}$ & $23.83 \mathrm{bc}$ & $34.17 \mathrm{~b}$ & $57.25 \mathrm{~b}$ \\
\hline $\begin{array}{l}\text { Crop- } \\
\text { ping } \\
\text { season }\end{array}$ & & $\begin{array}{l}\text { Yield } \\
\mathrm{kg} \mathrm{ha}^{-1}\end{array}$ & $\begin{array}{l}\text { Thousand } \\
\text { kernel } \\
\text { weight g }\end{array}$ & $\begin{array}{c}\text { Hardness } \\
\text { index }\end{array}$ & $\begin{array}{l}\text { Protein } \\
\text { content } \\
\%\end{array}$ & $\begin{array}{l}\text { Sedimentation } \\
\text { value (Zeleny) } \\
\mathrm{ml}\end{array}$ & $\begin{array}{l}\text { Wet } \\
\text { gluten } \\
\mathrm{g}\end{array}$ & $\begin{array}{c}\text { Gluten } \\
\text { index } \\
\%\end{array}$ & $\begin{array}{c}\text { Sedimentation } \\
\text { value (SDS) } \\
\text { ml }\end{array}$ & \\
\hline \multirow{6}{*}{$\begin{array}{c}2014- \\
2015\end{array}$} & Chamran-2 & $7443 \mathrm{a}$ & $40.46 \mathrm{ab}$ & $52.08 \mathrm{a}$ & $11.94 \mathrm{a}$ & $32.33 \mathrm{a}$ & $22.08 \mathrm{~b}$ & $52.67 \mathrm{~b}$ & $57.42 \mathrm{a}$ & \\
\hline & Parsi & $7233 \mathrm{a}$ & $41.11 \mathrm{ab}$ & $51.08 \mathrm{bc}$ & $11.57 \mathrm{c}$ & $32.08 \mathrm{abc}$ & $21.58 \mathrm{~b}$ & $43.67 \mathrm{bc}$ & $55.67 \mathrm{~b}$ & \\
\hline & Pishtaz & $6535 \mathrm{bc}$ & $39.45 \mathrm{~b}$ & $51.83 \mathrm{ab}$ & $11.78 \mathrm{~b}$ & $32.25 \mathrm{ab}$ & $21.67 \mathrm{~b}$ & $55.92 \mathrm{ab}$ & $56.42 \mathrm{~b}$ & \\
\hline & Bahar & 6838 abc & $36.96 \mathrm{c}$ & $50.17 \mathrm{c}$ & $11.56 \mathrm{c}$ & $31.75 \mathrm{c}$ & $22.67 \mathrm{ab}$ & $48.08 \mathrm{~b}$ & $56.00 \mathrm{~b}$ & \\
\hline & Sirwan & $6387 \mathrm{c}$ & $41.59 \mathrm{a}$ & $51.00 \mathrm{bc}$ & $11.67 \mathrm{bc}$ & $31.92 \mathrm{bc}$ & $24.08 \mathrm{a}$ & $66.25 \mathrm{a}$ & $56.08 \mathrm{~b}$ & \\
\hline & Sivand & $7071 \mathrm{ab}$ & $37.74 \mathrm{c}$ & $50.75 \mathrm{c}$ & $11.69 \mathrm{~b}$ & $32.08 \mathrm{abc}$ & $22.50 \mathrm{ab}$ & $35.08 \mathrm{c}$ & $56.67 \mathrm{ab}$ & \\
\hline
\end{tabular}

Note. SDS - sodium dodecyl sulphate; significant difference according to Duncan's multiple range test at $P$ level of $<0.05$ for different letters within each column.

classified as medium in quality (Table 5). In general, high protein content has been associated with good bread making quality (Horvat et al., 2015).

In average for all sowing dates, the sedimentation value (according to Zeleny) as a quick test for determination of the superior bread-making quality and gluten strength of wheat flour varied in the range of $32.75-33.83 \mathrm{ml}$ in the 2013-2014 and in the range of $31.75-32.33 \mathrm{ml}$ in the $2014-2015$ cropping seasons. It ranged from less than $20 \mathrm{ml}$ for very weak wheat up to $60 \mathrm{ml}$ for the strongest wheat. The sedimentation value (according to Zeleny) was between 55 to $60 \mathrm{ml}$ in both cropping seasons, showing that this type of wheat is most widely used for production of bread flour (Kurt-Polat, Yagdi, 2017). Wheat kernels obtained in the second year had lower moisture contents as compared to the first year, which may typically be attributed to higher temperature and drier climate during filling period. Kernel hardness is one of the main classification parameters for global wheat trade, which affects parameters such as milling yield, starch damage and baking properties (Sun et al., 2018).

The interaction of sowing date $\times$ cultivar on kernel yield in the 2013-2014 showed that the highest yield was obtained by 'Parsi' (11450 $\left.\mathrm{kg} \mathrm{ha}^{-1}\right)$ followed by 'Sirwan' $\left(11350 \mathrm{~kg} \mathrm{ha}^{-1}\right)$ sown on 7 November as the optimum sowing time (data not shown). Cultivars 'Bahar' (4033 kg ha-1) and 'Sivand' (4080 kg ha-1) when planted on 31 December (very late sown), produced the lowest yield (data not shown). In conclusion, yield in most of the cultivars significantly decreased under early or late sowing dates as compared to timely sowing.

According to the impact of interaction between sowing date and cultivar on kernel filling period in the 2014-2015 cropping season, the longest filling period was recorded for 'Bahar' (37 days) sown on 12 October (early sowing time) followed by 'Chamran-2', 'Parsi', 'Sivand' and 'Pishtaz', all were sown on 12 October (data not shown). The 'Sirwan' sown on 14 December (very late sowing time) had the shortest ( 25 days) filling period, which was statistically similar to that of 'Chamran-2' sown on 22 November and 14 December, 'Parsi' - on 14 December and 'Sirwan' - on 22 November (data not shown).

The ratio of wet gluten to kernel protein content was small and varied from 1.922 ('Chamran-2') to 2.111 ('Sirwan') in average for all sowing dates and years (data not shown). A regression line of gluten index on "wet gluten/protein" as indicator of wet gluten production per protein unit at four sowing dates across two years is shown in Figure 3.

It can be seen from the Figure 3 that a regression line for the second sowing date (timely-sown in November) showed improvement equal to $76.05 \%$
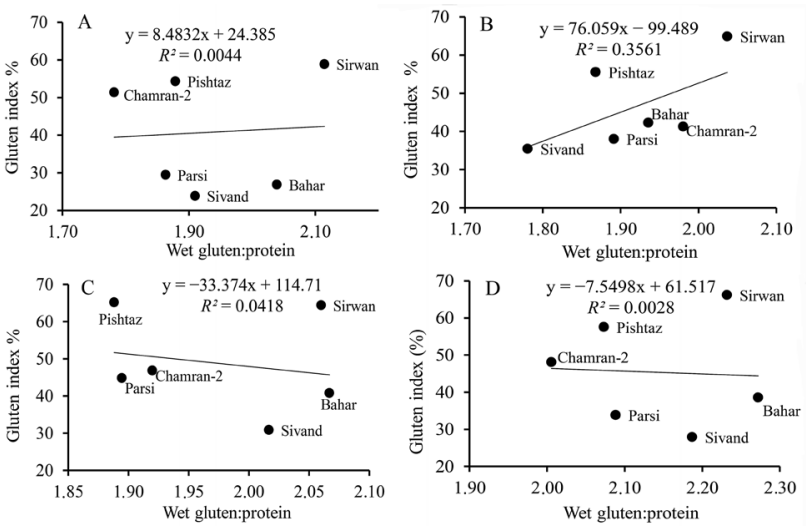

Figure 3. The relationship between the ratio of wet gluten to protein content and gluten index of spring wheat kernel under four sowing dates: early (A), timely (B), late (C) and very late (D)

per unit. This figure indicates that as long as wet gluten production per protein unit (WetG:PC ratio) at optimum sowing date is increased, the proportion of strong gluten per total gluten (as a desirable characteristic for dough elasticity) will be increased too. Hence, the highest gluten index was observed at higher ratio of wet gluten to protein content for timely-sown treatment.

Correlation between kernel components. Based on the results, significant positive correlation was found between yield and TKW $\left(r=0.309^{* *}\right)$ as well as yield and filling period $\left(r=0.531^{* *}\right)$, but yield had a significant negative influence $\left(r=-0.427^{* *}\right)$ on wet gluten (Table 6). This could possibly be attributed to the influence of protein content, because it has been previously reported in former studies that a negative correlation exists between these two traits (Amiri et al., $2015 ; 2018$ ), which was also evident in the current study. The results of the current study are in agreement with the findings of Surma et al. (2012), who reported negative correlation of wheat kernel yield with protein content, wet gluten and sedimentation value. Kernel filling period had significant and negative association with wet gluten $\left(r=-0.245^{*}\right)$ and gluten index $\left(r=-0.287^{*}\right)$. Hardness index was positively significantly correlated with protein content $\left(r=0.662^{* *}\right)$, sedimentation value (according to Zeleny) $\left(r=0.438^{* *}\right)$, water absorption ( $r$ $\left.=0.448^{* *}\right)$, gluten index $\left(r=0.291^{*}\right)$ and sedimentation value (according to SDS) $\left(r=0.287^{*}\right)$. A high statistically significant positive correlation was found for protein content with hardness index, sedimentation value (according to Zeleny), water absorption, gluten 
Table 6. Correlation coefficients of the studied spring wheat kernel traits using average of two cropping seasons $(\mathrm{n}=72)$

\begin{tabular}{|c|c|c|c|c|c|c|c|c|c|c|c|c|}
\hline & Y & TKW & FP & MP & HI & $\mathrm{PC}$ & Zel & BV & WA & WetG & GI & SDS \\
\hline $\mathrm{Y}$ & 1 & & & & & & & & & & & \\
\hline TKW & $0.309^{* *}$ & 1 & & & & & & & & & & \\
\hline FP & 0.531 ** & 0.024 & 1 & & & & & & & & & \\
\hline MP & -0.106 & -0.154 & -0.015 & 1 & & & & & & & & \\
\hline $\mathrm{HI}$ & -0.111 & 0.097 & 0.088 & 0.150 & 1 & & & & & & & \\
\hline PC & -0.056 & 0.140 & 0.015 & 0.041 & $0.662 * *$ & 1 & & & & & & \\
\hline Zel & -0.168 & 0.129 & -0.121 & 0.231 & $0.438^{* * *}$ & $0.575^{* *}$ & 1 & & & & & \\
\hline $\mathrm{BV}$ & -0.005 & 0.158 & -0.005 & -0.188 & 0.137 & 0.210 & 0.211 & 1 & & & & \\
\hline WA & -0.072 & 0.212 & -0.106 & 0.153 & $0.448^{* *}$ & $0.420 * *$ & $0.531 * *$ & 0.062 & 1 & & & \\
\hline WetG & $-0.427 * *$ & -0.024 & $-0.245^{*}$ & 0.088 & -0.061 & 0.088 & 0.141 & -0.161 & 0.094 & 1 & & \\
\hline GI & -0.148 & $0.266^{*}$ & $-0.287 *$ & 0.019 & $0.291 *$ & $0.384 * *$ & 0.150 & 0.214 & 0.157 & -0.068 & 1 & \\
\hline SDS & -0.003 & -0.073 & -0.044 & 0.104 & $0.287 *$ & $0.464 * *$ & $0.335 * *$ & 0.198 & 0.142 & 0.040 & $0.355 * *$ & 1 \\
\hline
\end{tabular}

Note. $\mathrm{Y}$ - yield, TKW - thousand kernel weight, $\mathrm{FP}$ - filling period, MP - moisture percent, $\mathrm{HI}$ - hardness index, $\mathrm{PC}$ - protein content, Zel - sedimentation value according to Zeleny, BV - bread volume, WA - water absorption, WetG - wet gluten, GI - gluten index, SDS - sedimentation value according to sodium dodecyl sulphate; *, ** - significant at the $P$ levels of $<0.05$ and $<0.01$, respectively.

index and sedimentation value.(according to SDS). The quality factors sedimentation values (according to SDS and Zeleny tests) were found to be positively significantly correlated with each other. Also sedimentation value (according to Zeleny) showed a significant correlation with water absorption (Table 6). Positive correlations between hardness index and sedimentation value (according to SDS), protein content and gluten index have been reported (Hruskova, Svec, 2009; Salmanowicz et al., 2012).

\section{Conclusions}

1. The results of the experiment showed that the performance of the studied cultivars was significantly better under timely sowing in mid-November compared to early (October) and late (December) sowing under Middle East climate conditions.

2. Most of the quality traits significantly and positively correlated among themselves, which can be considered as selection criteria for wheat improvement through providing information for wheat breeding programs as good technological quality.

3. The current study showed that spring wheat kernel quality and quantity were optimized for sowing dates during November in the years with the similar weather conditions. Therefore, the wheat quality and quantity of given cultivars can be improved by choosing an appropriate sowing date.

\section{Acknowledgements}

The authors would like to thank their colleagues from Kermanshah Agricultural and Natural Resources Research and Education Center and Cereals Technology and Chemistry Laboratory on Seed and Plant Improvement Institute. The current research was supported by Seed and Plant Improvement Institute, Agricultural Research Education and Extension Organization (AREEO), Iran, project No. 04-43-03-92327.

Received 04102019

Accepted 27032020

\section{References}

1. AACC. 2000. Adapted from Method 65-81B. American Associated of Cereal Chemists (10 $10^{\text {th }}$ ed.).

2. Amiri R., Bahraminejad S., Sasani S., Jalali-Honarmand S., Fakhri, R. 2015. Bread wheat genetic variation for grain's protein, iron and zinc concentrations as uptake by their genetic ability. European Journal of Agronomy, 67: 20-26. https://doi.org/10.1016/j.eja.2015.03.004

3. Amiri R. Sasani S., Jalali-Honarmand S., Rasaei A. Seifolahpour B., Bahraminejad S. 2018. Genetic diversity of bread wheat genotypes in Iran for some nutritional value and baking quality traits. Physiology and Molecular Biology of Plants, 24 (1): 147-157.

https://doi.org/10.1007/s12298-017-0481-4

4. Bassu S., Asseng S., Motzo R., Giunta F. 2009. Optimizing sowing date of durum wheat in a variable Mediterranean environment. Field Crops Research, 111: 109-118. https://doi.org/10.1016/j.fcr.2008.11.002
5. Coventry D. R., Gupta R. K., Poswal R. S., Chhokar R. S., Sharma R. K., Yadav V. K., Gill S. C., Mehta A., Kleemann S. G. L., Bonamano A., Cummins J. A. 2011. Wheat quality and productivity as affected by varieties and sowing time in Haryana, India. Field Crops Research, 123 (3): 214-225. https://doi.org/10.1016/j.fcr.2011.05.017

6. Dao H. Q., Byrne P. F., Reid S. D., Haley S. D. 2017. Validation of quantitative trait loci for grain quality-related traits in a winter wheat mapping population. Euphytica, 213 (5): 1-13. https://doi.org/10.1007/s10681-016-1793-0

7. Doneva S., Daskalova N., Spetsov P. 2018. Transfer of novel storage proteins from a synthetic hexaploid line into bread wheat. Zemdirbyste-Agriculture, 105 (2): 113-122. https://doi.org/10.13080/z-a.2018.105.015

8. Ferrari M. C., Clerici M. T. P. S., Chang Y. K. 2014. A comparative study among methods used for wheat flour analysis and for measurements of gluten properties using the wheat gluten quality analyser (WGQA). Food Science and Technology, 34 (2): 235-242.

https://doi.org/10.1590/fst.2014.0038

9. Gazza L., Galassi E., Ciccoritti R., Cacciatori P., Pogna N. E. 2016. Qualitative traits of perennial wheat lines derived from different Thinopyrum species. Genetic Resources and Crop Evolution, 63: 209-219. https://doi.org/10.1007/s10722-015-0240-8

10. Guarda G., Padovan S., Delogu G. 2004. Grain yield, nitrogen use efficiency and baking quality of old and modern Italian bread wheat cultivars grown at different nitrogen levels. European Journal of Agronomy, 21: 181192. https://doi.org/10.1016/j.eja.2003.08.001

11. Horvat D., Drezner G., Sudar R., Simici G., Dvojkovici K., Spanici V., Magdici D. 2015. Distribution of wheat protein components under different genetic backgrounds and environments. Turkish Journal of Field Crops, 20 (2): 150-154. https://doi.org/10.17557/tjfc. 12437

12. Hruskova M., Svec I. 2009. Wheat hardness in relation to other quality factors. Czech Journal of Food Sciences, 27 (4): 240-248. https://doi.org/10.17221/71/2009-CJFS

13. Jiang D., Yue H., Wollenweber B., Tan W., Mu W., Bo Y., Dai T., Cao W. 2009. Effects of postanthesis drought and waterlogging on accumulation of high-molecular-weight glutenin subunits and glutenin macropolymers content in wheat grain. Journal of Agronomy and Crop Science, 195 (2): 89-97. https://doi.org/10.1111/j.1439-037X.2008.00353.X

14. Kong L., Si J., Zhang B., Feng B., Li S., Wang F. 2013. Environmental modification of wheat grain protein accumulation and associated processing quality: a case study of China. Australian Journal of Crop Science, 7 (2): 173-181.

15. Koppel R., Ingver A. 2010. Stability and predictability of baking quality of winter wheat. Agronomy Research, 8: 637-644.

16. Kristó I., Gyuris K., Torma M., Hódi-Szél M., Petróczi I. M. 2007. Investigation of sowing date and seeding rate on the yield of winter wheat. Cereal Research Communications, 35: 685-688. https://doi.org/10.1556/CRC.35.2007.2.130

17. Kurt-Polat P. O., Yagdi K. 2017. Investigations on the relationships between some quality characteristics in a winter wheat population. Turkish Journal of Field Crops, 22 (1): 108-113. https://doi.org/10.17557/tifc.311016

18. Laidig F., Piepho H. P., Rentel D., Drobek T., Meyer U. Huesken A. 2017. Breeding progress, environmental variation and correlation of winter wheat yield and quality traits in German official variety trials and on-farm during 1983-2014. Theoretical and Applied Genetics, 130: 223-245. https://doi.org/10.1007/s00122-016-2810-3 
19. Mastromatteo M., Guida M., Danza A., Laverse J., Frisullo P., Lampignano V., Del Nobile M. A. 2013. Rheological, microstructural and sensorial properties of durum wheat bread as affected by dough water content Food Research International, 51: 458-466. https://doi.org/10.1016/i.foodres.2013.01.004

20. Nadew B. B. 2018. Effects of climatic and agronomic factors on yield and quality of bread wheat (Triticum aestivum L.) seed: a review on selected factors. Advances in Crop Science and Technology, 6 (2): 2-5.

21. Nikola N., Mladenov N., Djuric V., Kondic-Spika A., Marjanovic-Jeromela A., Simic D. 2010. Genotype by environment interactions in wheat quality breeding programs in southeast Europe. Euphytica, 174 (3): 315324. https://doi.org/10 1007/s10681-009-0100-8

22. Osborne B. G., Henry R., Southan, M. D. 2007. Assessment of commercial milling performance of hard wheat by measurement of the rheological properties of whole grain Journal of Cereal Sciences, 45: 122-127.

https://doi.org/10.1016/j.jcs.2006.07.005

23. Pan J., Jiang D., Dai T. B., Lan T., Cao W.-X. 2005. Variation in wheat grain quality grown under different climate conditions with different sowing dates. Acta Phytoecologica Sinica, 29: 467-473, https://doi.org/10.17521/cjpe. 2005.0062

24. Peña R. J., Trethowan R., Pfeiffer W. H., van Ginkel M. 2002. Quality (end-use) improvement in wheat. Journal of Crop Production, 5 (1): 1-37.

https://doi.org/10.1300/J144v05n01 02

25. Salmanowicz B. P., Adamski T., Surma M., Kaczmarek Z., Krystkowiak K., Kuczyńska A., Banaszak Z., Ługowska B., Majcher M. A., Obuchowski W. 2012. The relationship between grain hardness, dough mixing parameters and bread-making quality in winter wheat. International Journal of Molecular Sciences, 13 (4): 4186-4201. https://doi.org/10.3390/ijms13044186

26. Silva R. R., Benin G., Almeida J. L. D., Fonseca I. C. D. B., Zucareli C. 2014. Grain yield and baking quality of wheat under different sowing dates. Acta Scientiarum Agronomy, 36 (2): $201-210$ https://doi.org/10.4025/actasciagron.v36i2.16180

27. Simons K., Anderson J. A., Mergoum M., Faris J. D. Klindworth D. L., Xu S. S., Sneller C., Ohm J.-B., Hareland G. A., Edwards M. C., Chao S. 2012. Genetic mapping analysis of bread-making quality traits in spring wheat. Crop Science, 52: 2182-2197.

https://doi.org/10.2135/cropsci2012.03.0175
28. Singh S., Gupta A. K., Kaur N. 2010. Effect of sowing time on protein quality and starch pasting characteristics in wheat (Triticum aestivum L.) genotypes grown under irrigated and rain-fed conditions. Food Chemistry, 122 (3): 559-563. https://doi.org/10.1016/j.foodchem.2010.03.010

29. Sivam A. S., Sun-Waterhouse D., Quek S. Y., Perera C. O. 2010. Properties of bread dough with added fiber polysaccharides and phenolic antioxidants: a review. Journal of Food Science, 75: 163-174. https://doi.org/10.1111/j.1750-3841.2010.01815.x

30. Sun X., Liu T., Ning T., Liu K., Duan X., Wang X., Wang Q., An Y., Guan X., Tian J.-C., Chen J.-S. 2018. Genetic dissection of wheat kernel hardness using conditional QTL mapping of kernel size and protein-related traits. Plant Molecular Biology Reporter, 36: 1-12. https://doi.org/10.1007/s11105-017-1061-z

31. Surma M., Adamski T., Banaszak Z., Kaczmarek Z., Kuczyńska H., Majcher M., Krystkowiak K. 2012. Effect of genotype, environment and their interaction on quality parameters of wheat breeding lines of diverse grain hardness. Plant Production Science, 15 (3): 192-203. https://doi.org/10.1626/pps.15.192

32. Tapley M., Ortiz B. V., Santena E. V., Balkcomb K. S. Maska P., Weavera D. B. 2013. Location, seeding date, and variety interactions on winter wheat yield in southeastern United States. Agronomy Journal, 105: 509-518. https://doi.org/10.2134/agronj2012.0379

33. Williams P., El-Haramein F. J., Nakkoul H., Rihawi S. 1988. Crop quality evaluation methods and guidelines $\left(2^{\text {nd }}\right.$ ed.). International Center for Agricultural Research in the Dry Areas (ICARDA), Aleppo, Syria, $145 \mathrm{p}$

34. You L., Rosegrant M. W. Wood S., Sun D. 2009. Impact of growing season temperature on wheat productivity in China. Agricultural and Forest Meteorology, 149 (6-7): 10091014. https://doi.org/10.1016/j.agrformet.2008.12.004

35. Zecevic V., Boskovic J., Knezevic D., Micanovic D. 2014. Effect of seeding rate on grain quality of winter wheat. Chilean Journal of Agricultural Research, 74 (1): 23-28. https://doi.org/10.4067/S0718-58392014000100004

36. Zhang Y., He Z., Zhang A., Van Ginkel M., Ye G. 2006. Pattern analysis on grain yield performance of Chinese and CIMMYT spring wheat cultivars sown in China and CIMMYT. Euphytica, 147 (3): 409-420. https://doi.org/10.1007/s10681-005-9038-7

ISSN 1392-3196 / e-ISSN 2335-8947

Zemdirbyste-Agriculture, vol. 107, No. 3 (2020), p. 279-286

DOI $10.13080 /$ z-a.2020.107.036

\title{
Sẻjos laiko ịtaka duoninių kviečių grūdų kiekybiniams ir kokybiniams rodikliams Vidurio Rytų klimato sąlygomis
}

\author{
S. Sasani ${ }^{1}$, R. Amiri' ${ }^{2}$ H. R. Sharifi ${ }^{3}$, A. Lotfi ${ }^{1}$ \\ Irano žemès ūkio tyrimų, švietimo ir konsultavimo organizacijos \\ ${ }^{1}$ Kermanshah žemès ūkio ir gamtos išteklių tyrimų ir švietimo centras, \\ ${ }^{2}$ Lorestan žemès ūkio ir gamtos išteklių tyrimų ir švietimo centras, \\ ${ }^{3}$ Khorasan Razavi žemės ūkio ir gamtos išteklių tyrimų ir švietimo centras
}

\section{Santrauka}

Dvejus metus buvo tirta vasarinio kviečio (Triticum aestivum L.) šešiu komerciniu veislių, keturiu sẻjos laiku (ankstyva sèja, sèja optimaliu laiku, vėlyva sèja bei labai vėlyva sèja) ir jų sąveikos įtaka grūdų kiekybinėms ir kokybinėms savybėms. Dispersinė analizè (ANOVA) parodè, kad sèjos laiko ịtaka buvo reikšminga tik grūdu derliui ir užpildymo trukmei. Grūdų kokybinèms savybėms sèjos laikas neturejjo reikšmingos įtakos. Sejjos laiko $\times$ veislès $\times$ metu sąveika buvo reikšminga kai kurioms grūdu kiekybinėms ir kokybinèms savybėms - derliui, užpildymo trukmei, sedimentacijos vertei ir glitimo indeksui. Visų veislių grūdų derlius juos pasèjus vẻlai ir labai vèlai sumažèjo 34 ir 50\%, palyginus su 2013-2014 m. augintu ir optimaliu laiku (lapkričio mènesí) pasètu vasarinių kviečių derliumi, ir 25 bei $38 \%$, palyginus su augintų 2014-2015 m. Daugumai tirtų požymių metų itaka buvo didesnè nei veislès arba sėjos laiko. Veislès itaka buvo reikšminga 1000 grūdu masei, vidutiniškai reikšminga glitimo indeksui ir nedidelè kitiems rodikliams. Sejjos laikas didžiausią ịtaką turèjo grūdų derliui, užpildymo trukmei ir šlapio glitimo kiekiui. Nustatytas neigiamas ryšys tarp kokybès rodiklių ir grūdų derliaus, tačiau kokybės rodikliai reikšmingai ir teigiamai koreliavo tarpusavyje. Eksperimento rezultatai leidžia teigti, kad kviečių kokybinị ir kiekybinị potencialą galima išnaudoti juos sèjant optimaliu laiku.

Reikšminiai žodžiai: glitimas, grūdų derlius, sėjos laikas, 1000 grūdų masė, Zeleny ir SDS sedimentacijos vertès. 